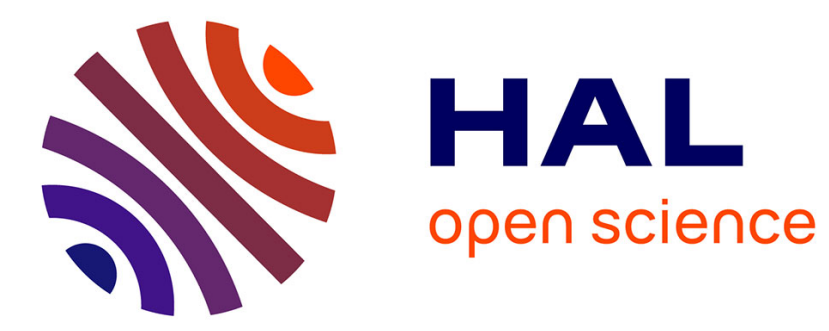

\title{
Comparison of the development in planta of a pyrrolnitrin-resistant mutant of Botrytis cinerea and its sensitive wild-type parent isolate
}

\author{
Sakhr Ajouz, Marc Bardin, Philippe C. Nicot, Mohamed El Maâtaoui
}

\section{- To cite this version:}

Sakhr Ajouz, Marc Bardin, Philippe C. Nicot, Mohamed El Maâtaoui. Comparison of the development in planta of a pyrrolnitrin-resistant mutant of Botrytis cinerea and its sensitive wild-type parent isolate. European Journal of Plant Pathology, 2011, 129 (1), pp.31-42. 10.1007/s10658-010-9638-5 . hal-01332259

\section{HAL Id: hal-01332259 \\ https://hal.science/hal-01332259}

Submitted on 29 May 2020

HAL is a multi-disciplinary open access archive for the deposit and dissemination of scientific research documents, whether they are published or not. The documents may come from teaching and research institutions in France or abroad, or from public or private research centers.
L'archive ouverte pluridisciplinaire HAL, est destinée au dépôt et à la diffusion de documents scientifiques de niveau recherche, publiés ou non, émanant des établissements d'enseignement et de recherche français ou étrangers, des laboratoires publics ou privés.

\section{(ㄷ)(1) $\$$}

Distributed under a Creative Commons Attribution - NonCommerciall 4.0 International 
Version définitive du manuscrit publié dans / Final version of the manuscript published in : European Journal of Plant pathology, 2011, 129, 31-42, DOI: 10.1007/s10658-010-9638-5. The original publication is available at www.springerlink.com.

\title{
Comparison of the development in planta of a pyrrolnitrin-resistant mutant of Botrytis cinerea and its sensitive wild-type parent isolate
}

\author{
Sakhr Ajouz, Marc Bardin, Philippe C. Nicot and Mohamed El Maâtaoui
}

\author{
S. Ajouz, M. Bardin ( $\square)$, P. C. Nicot \\ INRA, UR407, Plant Pathology Unit, Domaine St Maurice, F-84140 Montfavet, France \\ e-mail: marc.bardin@avignon.inra.fr \\ Phone: +33432722855 . Fax: +33432722842
}

\author{
M. El Maâtaoui \\ Université d'Avignon, BP 21239 F-84916 Avignon Cedex 9 \\ INRA, UMR 406 UAPV/INRA, F-84914 Avignon, France
}

Keywords aggressiveness, cytopathology, fitness, light microscopy, near-isogenic lines, tomato plant; experimental evolution

\begin{abstract}
Botrytis cinerea is able to build-up resistance to pyrrolnitrin, an antibiotic produced by diverse biocontrol agents, possibly compromising the durability of this method of disease control. The development of two near-isogenic lines of $B$. cinerea differing in their level of resistance to pyrrolnitrin was compared in tomato plants and on PDA medium. In tomato plants, significant differences in the percentage of infected petioles one day after inoculation and in symptom progression on petioles and stems were observed between the resistant mutant and the sensitive wild-type parent suggesting a difference in their level of aggressiveness. Cytohistological investigations revealed that conidia of both near-isogenic lines germinated 6 hours after inoculation and mycelium developed within petiole tissues 12 hours after inoculation. However, while the wild-type parent isolate spread throughout the petiole and rapidly invaded the stem tissues via the leaf-abscission zone 72 hours after inoculation, the pyrrolnitrin-resistant mutant failed to extend beyond petiole tissues to invade the stem. Moreover, 72 hours after inoculation, the mycelial development of the pyrrolnitrin-resistant mutant was accompanied by abnormal glycogen accumulation and chlamydospore-like cells formation. In contrast, wild-type parent mycelium was normally structured with intensive colonization of stem tissues. Additionally, on PDA medium the mycelium of the pyrrolnitrin-resistant mutant was less vigorous than the wild-type isolate. These results suggest that the acquisition of pyrrolnitrinresistance in $B$. cinerea is accompanied by changes in mycelial structure and reduction in mycelial growth, leading to a noticeable loss of aggressiveness on tomato plants.
\end{abstract}




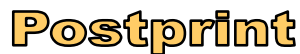

Version définitive du manuscrit publié dans / Final version of the manuscript published in : European Journal of Plant pathology, 2011, 129, 31-42, DOI: 10.1007/s10658-010-9638-5. The original publication is available at www.springerlink.com.

\section{Introduction}

Grey mould, caused by the fungus Botrytis cinerea Pers.:Fr (teleomorph Botryotinia fuckeliana [(de Bary) Whetzel)], is a severe disease on a wide range of economically important crops. Disease control generally relies on fungicides (Leroux 2004; Rosslenbroich and Stuebler 2000), although biological control strategies have been intensively studied over the last three decades (Blakeman and Fokkema 1982; Elad and Stewart 2004). In greenhouse production of tomato, this fungus can develop on leaves, stems, flowers and fruits (Dik and Wubben 2004). On stems, symptoms consist of cankers, which result from the infection of the pruning wounds caused by the removal of leaves throughout the growing season (Dik and Wubben 2004). Leaves are periodically removed from the lower part of the stems, usually from the time of ripening of the first fruit cluster and until the end of the season (Decognet et al. 2010). Infection by B. cinerea occurs when conidia deposit on wounded plant tissues. The development of stem cankers generally results in the death of the infected plant.

Due to the multinucleate state of its hyphal compartments and of its conidia (Büttner et al. 1994), $B$. cinerea exhibits high-genetic variability with strains differing in their aggressiveness on tomato plants (Decognet et al. 2009). It is considered a high-risk pathogen in terms of resistance to fungicides (Leroux 2004). Several laboratory experiments have shown that this fungus can evolve rapidly under strong selection pressure (Ajouz et al. 2010; Faretra and Pollastro 1993; Nicot et al. 2001). In a previous in vitro study, we have selected mutants of $B$. cinerea differing in their level of resistance to pyrrolnitrin (3-chloro-4-(2' -nitro-3' -chlorophenyl)-pyrrole) (Ajouz et al. 2010). This antibiotic is produced by various bacteria described as potential biological control agents against B. cinerea (Chernin et al. 1996; Janisiewicz and Roitman 1988) and resistance to this antibiotic may constitute a risk of build-up of resistance to pyrrolnitrinproducing biocontrol agents in the field. In our study, however, this resistance was associated with a high fitness cost for all the mutants that were examined, suggesting reduced risks of complete loss of efficacy by pyrrolnitrin-producing biological control agents in the field (Ajouz et al. 2010). Nevertheless, the stability of resistance observed in the previous study (Ajouz et al. 2010) may pose a greater risk, if subsequent mutations could improve the fitness of the resistant variants as already observed for fungicide-resistant Aspergillus nidulans isolates (Schoustra et al. 2006).

The infection of susceptible plants by Botrytis species is mediated by complex processes (Holz et al. 2004), essentially involving an extensive arsenal of pectinolytic enzymes that allow tissue invasion by the mycelium (Kars and Van Kan 2004; Shah et al. 2009; Staples and Mayer 1995). The extracellular enzymes and metabolites that mediate pathogenesis have been extensively studied on tomato (for review see Kars and Van Kan 2004). Histological observations have been achieved in various plant tissues, such as Arabidopsis (Van Baarlen et al. 2007), onion leaves (Clark and Lorbeer 1976), grapes (Glidewell et al. 1997; Viret et al. 2004) and tomato fruits (Charles et al. 2008; Rijkenberg et al. 1980) and leaves (Prins et al. 2000). But little is known about cytohistological comparison of infection of tomato petioles stubs and stems by $B$. cinerea isolates differing in their level of aggressiveness.

The objective of this study was to compare the behaviour of two near-isogenic lines of $B$. cinerea, differing in their level of resistance to the antibiotic pyrrolnitrin, on artificially inoculated petioles and stems of tomato plants and in vitro cultures. To test the hypothesis whether the reduction of sensitivity to pyrrolnitrin was correlated with reduced ability to invade plant tissues, the development of infection in tomato tissues was monitored in terms of lesion development and cytohistology. This knowledge is important to estimate the durability of efficacy of pyrrolnitrin-producing biological control agents against $B$. cinerea. 


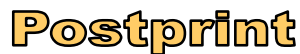

Version définitive du manuscrit publié dans / Final version of the manuscript published in : European Journal of Plant pathology, 2011, 129, 31-42, DOI: 10.1007/s10658-010-9638-5. The original publication is available at www.springerlink.com.

\section{Material and methods}

Botrytis cinerea isolates and inoculum production

The wild type parent isolate $\mathrm{BC} 1$ of $B$. cinerea (referred to as "BC1G0" in the rest of the paper) was obtained from an infected tomato plant in Plougastel (France) in 1989. This isolate was selected for its high level of aggressiveness on tomato plants (Decognet et al. 2009) and its sensitivity to pyrrolnitrin (Ajouz et al. 2010). In previous work, twenty successive spore generations of this isolate were produced in Petri dish on Potato Dextrose Agar (PDA) media (39 $\mathrm{g} \mathrm{l}^{-1}$; Difco Laboratory, Detroit, Michigan) amended with the antibiotic pyrrolnitrin (Ajouz et al. 2010). This resulted in the isolation of pyrrolnitrin-resistant mutants of $\mathrm{BC} 1$, one of which was selected for the present study, and will be referred to as "BC1G20P" in the rest of the paper (Ajouz et al. 2010). These two near-isogenic lines have been maintained in stock cultures stored at $-20^{\circ} \mathrm{C}$ in a $0.06 \mathrm{M}$, phosphate buffer $(\mathrm{pH} 4.5)$ containing $20 \%(\mathrm{~V} / \mathrm{V})$ glycerol.

Inoculum of BC1G0 and BC1G20P was produced in Petri dish on PDA media incubated under cool white fluorescent light (14-hour photoperiod $-65 \mu$ mole $\mathrm{m}^{-2} \mathrm{~s}^{-1}$ ) in a growth chamber at $21^{\circ} \mathrm{C}$. Conidia were collected in $5 \mathrm{ml}$ of sterile distilled water from 14-day-old cultures. The suspensions were vortexed for 1 minute with $5 \mathrm{~g}$ of glass beads $(2.5 \mathrm{~mm}$ diameter) to separate the spores and then filtered through $30 \mu \mathrm{m}$ mesh filters to remove mycelial fragments. The final concentration of the suspensions was adjusted to $10^{6}$ conidia per $\mathrm{ml}$ using a hemacytometer.

\section{In vitro fungal growth}

For each isolate, $\mathrm{BC} 1 \mathrm{G} 0$ and $\mathrm{BC} 1 \mathrm{G} 20 \mathrm{P}$, the rate of mycelial growth was determined on PDA media in $90-\mathrm{mm}$ Petri plates. Inoculation of B. cinerea was done in the centre of the plate with a 5-mm diameter mycelial plug excised from three-day old non-sporulated cultures. The inoculated plates were incubated at $21^{\circ} \mathrm{C}$ with alternating periods of dark (10 hours) and light (14 hours). The daily radial growth rate was measured in mm between 1 and 4 days after inoculation. Three replicated plates were used per isolate and the whole experiment was conducted independently three times. Statistical analysis was performed to compare the mycelial growth rate between BC1G0 and BC1G20P by $t$-test with Statistica Kernel version 5.5 software (Statsoft Inc., Tulsa, AZ, USA).

\section{Aggressiveness on tomato plants}

The aggressiveness of BC1G0 and BC1G20P was investigated on 6-8 week-old tomato plants cv. Monalbo (INRA, Avignon, France). Plants were grown in a greenhouse in individual pots containing a horticultural mix (De Baat, Coevorden, The Netherlands) and watered daily with a nutrient solution. Two types of bioassays were used with two independent sets of plants. The first bioassay method was to compare the level of aggressiveness between BC1G0 and BC1G20P on the petioles. Three leaves were removed from each of three plants per isolate, leaving 50-mm petiole stubs on the stems. Each petiole was inoculated with $10 \mu \mathrm{l}$ aliquots of a spore suspension. Three non-inoculated plants were used as a control. The 50-mm petiole stubs were examined for infection and the length of each developing petiole lesion was monitored daily for 7 days after inoculation. The results were expressed as percentages of infected petioles. The aggressiveness of $\mathrm{BC} 1 \mathrm{G} 20 \mathrm{P}$ was compared to that of $\mathrm{BC} 1 \mathrm{G} 0$ by examining the dynamics of lesion development on the petiole stubs and by computing the area under the disease progress curve (AUDPC) between 1 and 5 days after inoculation (Decognet et al. 2009). 


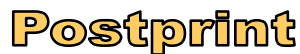

Version définitive du manuscrit publié dans / Final version of the manuscript published in : European Journal of Plant pathology, 2011, 129, 31-42, DOI: 10.1007/s10658-010-9638-5. The original publication is available at www.springerlink.com.

The second bioassay method was to compare the level of aggressiveness between BC1G0 and BC1G20P on the stems of the tomato plants. Three leaves were removed from each of three plants per isolate, leaving $5-10 \mathrm{~mm}$ petiole stubs on the stems. Each pruning wound was inoculated with $10 \mu \mathrm{l}$ aliquots of a spore suspension. Three non-inoculated plants were used as a control. The length of resulting stem lesions was monitored daily for 7 days after inoculation. The aggressiveness of $\mathrm{BC} 1 \mathrm{G} 20 \mathrm{P}$ was compared to that of BC1G0 by examining the dynamics of lesion development on the stems. Disease development on stems for BC1G0 and BC1G20P were assessed by computing the AUDPC between 1 and 7 days after inoculation (Decognet et al. 2009). In addition, detachment of petiole stubs from the stem was compared 3 days after inoculation between the BC1G20P inoculated plants and the non-inoculated plants.

All plants were incubated in a growth chamber with a photoperiod of 14 hours maintained at $21^{\circ} \mathrm{C}$ with a relative humidity above $90 \%$. Three plants were inoculated for each isolate and the bioassays were repeated three times.

The percentages of infected petioles and the values of AUDPC of BC1G20P were statistically compared with those of BC1G0 by $t$ test, using the average values for each of the three assays as elementary replicates. Daily comparisons of lesion size between BC1G20P and BC1G0 were also analysed by $t$ test. Statistical analyses were done with Statistica software.

\section{Cytohistology}

Samples of petiole and stem fragments were excised from the region between the healthy and the infected tissues of five tomato plants inoculated with either BC1G0 or BC1G20P on 5-10 mm petiole stubs as described above. Sampling was carried out 6, 12, 24, 48, 72 and 120 hours after inoculation. The samples were immersed for 12 hours at $4^{\circ} \mathrm{C}$ in a fixative solution (4\% paraformaldehyde in $0.1 \mathrm{mM}$ phosphate buffer, $\mathrm{pH}$ 7.2). Fixed specimens were dehydrated in a graded ethanol series (70-100\%) and embedded in methacrylate resin (Technovit Kulzer 7100, Heraeus Kulzer, Wehrheim, Germany). The specimens were orientated to obtain longitudinal sections. After resin polymerization at room temperature, the blocks were cut into 3- $\mu \mathrm{m}$ thick ribbons on an automatic retracting microtome (Supercut 2065; Reichert-Jung, Leica Intruments, Nussloch, Germany) equipped with disposable knives (Histoknife H; Heraeus-Kulzer). Sections were mounted on slides and stained using the periodic acid shiff (PAS) procedure to visualize polysaccharides (pink) and naphtol blue black (NBB) to visualize proteins (dark blue) (El Maâtaoui and Pichot 1999). Observations were performed using a Leica DMR light microscope. Images were captured using a Leica DFC 300 FX digital camera and analysed using LAS software (Leica). At least three samples were observed for each stage. Attention was paid to spore germination, mycelium structure and progression in petiole and stem tissues, and cytopathological effects.

\section{Results}

Aggressiveness on tomato plants

The aggressiveness of the pyrrolnitrin-sensitive wild-type parent isolate BC1G0 was compared with that of the pyrrolnitrin-resistant mutant BC1G20P on tomato plants based on the two types of bioassays. Tests on 50-mm petiole stubs revealed that the frequency of petiole infection was significantly different between BC1G0 (77.8\% of infected petiole) and BC1G20P (22.2\% of infected petiole), one day after inoculation $(P=0.03)$, even if symptom development was limited for both lines $(<2 \mathrm{~mm}$, Fig. 1). Two days after inoculation, both $B$. cinerea near-isogenic lines were able to attack all the petiole stubs, and the size of petiole lesions were not significantly 


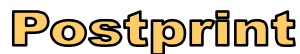

Version définitive du manuscrit publié dans / Final version of the manuscript published in : European Journal of Plant pathology, 2011, 129, 31-42, DOI: 10.1007/s10658-010-9638-5. The original publication is available at www.springerlink.com.

different (Fig. 1, $P>0.05$ ). Significant quantitative differences were observed between BC1G0 and $\mathrm{BC} 1 \mathrm{G} 20 \mathrm{P}$ for the subsequent development of petiole lesions (Fig. 1). After 5 days of incubation, the pyrrolnitrin-sensitive wild-type parent isolate BC1G0 almost reached the end of the 50 -mm long petiole $(45.4 \pm 1.7 \mathrm{~mm})$ while BC1G20P invaded only $21.5 \pm 3.6 \mathrm{~mm}$ of the petiole (Fig. 1). Even 7 days after inoculation, the pyrrolnitrin-resistant mutant BC1G20P did not invade the entire petiole (Fig. 1). The general progression of infection in the 50-mm long petioles was significantly different between BC1G0 and BC1G20P ( $t$ test on AUDPC values, $P=$ 0.007).

The evaluation of aggressiveness on tomato stems revealed that the pyrrolnitrin-sensitive wildtype parent isolate $\mathrm{BC} 1 \mathrm{G} 0$ readily colonized the $5-10 \mathrm{~mm}$ petiole stub and infected the stem, while lesion development was very limited for BC1G20P (Fig. 2). Differences in the lesion size between BC1G0 and BC1G20P become evident from the fourth day and increase until the end of the experiment. The general progression of infection on the stems was significantly different between BC1G0 and BC1G20P ( $t$ test on AUDPC values, $P<0.001)$. Most of the time, the pyrrolnitrin-resistant mutant $\mathrm{BC} 1 \mathrm{G} 20 \mathrm{P}$ failed to attack the stems and only caused a brown discoloration of the stem tissue at the leaf-abscission zone, whereas when the petiole is removed from the control non-inoculated plants, the stem is not coloured in this area (Fig. 3). For this mutant, the size of the stem lesions rarely increased beyond the diameter of the petiole (Fig. 3b). In addition, inoculation with BC1G20P stimulated the detachment of the petiole stubs from the tomato stem (24.4\% of detachment, 3 days after inoculation), while the petioles rarely detached from the stem when they were inoculated with the parent isolate BC1G0 ( $<3 \%$ of detachment) and never detached from the stem for the control non-inoculated plants (Fig. 3c).

\section{Cytohistolology}

Sections from petiole fragments fixed 6 hours after inoculation revealed that spores of BC1G0 and BC1G20P germinated within the cut cells of petiole tissues (Fig. 4a ,b). The germinated spores formed thin germ tubes which initiated the penetration of the cells and the intercellular spaces particularly in cortical and medullar parenchyma (Fig. 4c, d). Observations of sections performed 12, 24, and 48 hours after inoculation showed different degrees of mycelium proliferation and colonization of petiole tissues with no obvious differences between BC1G0 and BC1G20P. Twelve hours after inoculation, hyphae began to extend to inner tissues where they developed intra and intercellularly (Fig. 4c, d). Sections from petioles 24 hours after inoculation showed mycelial development for both BC1G0 and BC1G20P (Fig. 4e, f). At this stage of infection, hyphae were observed to have colonised all tissues where the cell wall broke down and cell collapse took place (Fig. 4e, f). Forty-eight hours after inoculation, the infection progressed deeply into petiole tissues with intensive cell wall lysis and cell death (Fig. 5a, b). At these early stages of infection, BC1G0 and BC1G20P exhibited similar capacities for tissue invasion and cytopathological alterations. However, 72 hours after inoculation evident differences appeared. At a structural level, the mycelium compartments of BC1G20P were shorter than the mycelium compartments of the parent isolate BC1G0 (Fig. 5c, d). Moreover, the mycelium compartments of BC1G20P exhibited important glycogen accumulation as attested by the presence of voluminous, PAS-positive granules in the cytoplasm, compared to BC1G0 (Fig. 5e, f). Cells of BC1G20P hyphae presented spherical shapes and separated from each other via septum disintegration thus producing chlamydospore-like structures (Fig. 5c, e). Another difference was observed concerning hyphal structure, particularly in apex compartments. For BC1G0 they were normally shaped with rigid walls and pointed apices, while for BC1G20P they appeared shrunken with undulating walls and rounded apices (Fig. 6a, b). The BC1G0-inoculated samples displayed generalized invasion by the mycelium. In addition, many hyphae reached the leaf- 


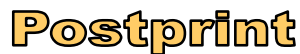

Version définitive du manuscrit publié dans / Final version of the manuscript published in : European Journal of Plant pathology, 2011, 129, 31-42, DOI: 10.1007/s10658-010-9638-5. The original publication is available at www.springerlink.com.

abscission zone where they created breaches from which they initiated the invasion of stem tissues (Fig. 6d). In contrast, the mycelium of BC1G20P was absent from this zone (Fig. 6c). Sections made 120 hours after inoculation showed that the mycelium of BC1G20P was confined to the peripheral tissues of the petiole with no stem infection, whereas BC1G0 mycelium was extended and invaded all stem tissues (Fig. 6e, f). Particularly damaged plant structures were parenchyma and collenchyma tissues (Fig. 6f).

In vitro mycelial growth

Significant differences in mycelial growth on PDA medium between BC1G0 and BC1G20P were observed throughout the experiment duration $(P<0.001$ at 3 days after inoculation, Fig. 7). The development of BC1G20P was reduced compared to that of the pyrrolnitrin-sensitive wildtype parent isolate $\mathrm{BC} 1 \mathrm{G} 0$. While the colony of $\mathrm{BC} 1 \mathrm{G} 0$ reached the edge of the $90-\mathrm{mm}$ diameter Petri dish after 4 days of incubation, the colony diameter of the BC1G20P pyrrolnitrin-resistant mutant was $51 \pm 0.6 \mathrm{~mm}$ (Fig. 7).

\section{Discussion}

The reduction in sensitivity of $B$. cinerea to pyrrolnitrin was associated with a reduced ability to invade tomato plant tissues. Differences in the aggressiveness between the pyrrolnitrin-resistant mutant $\mathrm{BC} 1 \mathrm{G} 20 \mathrm{P}$ and its sensitive wild-type parent isolate $\mathrm{BC} 1 \mathrm{G} 0$ have been observed in both petioles and stems of tomato plants. The observed differences were not related to the early stages of infection as the conidia of both BC1G0 and BC1G20P germinated as early as 6 hours after inoculation and the germ-tubes proliferated and colonized the petiole tissues. Rather, these differences in aggressiveness may be linked to the observed reduced mycelial growth rate of the mutant compared to the wild type parent. This difference in mycelial growth is in accordance with results of a previous study which showed that mutants of $B$. cinerea resistant to the phenylpyrrole fungicide fludioxonil, a synthetic analogue of pyrrolnitrin, displayed significant reduction in mycelial growth compared to their fludioxonil-sensitive wild type parental isolates (Ziogas et al. 2005). A recent study reported that all tested mutants of Penicillium expansum with high resistance to fludioxonil grew significantly slower on PDA at $20^{\circ} \mathrm{C}$ compared with the wild-type parental isolates ( $\mathrm{Li}$ and Xiao 2008). The mechanisms of resistance to phenylpyrroles have been extensively studied in fungal plant pathogens, and particularly in B. cinerea, revealing that an osmosensing histidine kinase mediates resistance to this family of fungicide (Avenot et al. 2005; Liu et al. 2008). Besides being involved in resistance to other fungicides in addition to phenylpyrroles, this histidine kinase is also believe to be responsible for adaptation to adverse environmental conditions, reduction of mycelial growth and decrease in pathogenicity (Liu et al. 2008; Viaud et al. 2006).

To test whether the observed reduction of $\mathrm{BC} 1 \mathrm{G} 20 \mathrm{P}$ aggressiveness was correlated with reduced ability to invade plant tissues, we performed histological studies in light microscopy by periodic sectioning of inoculated samples. It appeared that even if up to 72 hours, BC1G0 and BC1G20P were able to form mycelium within tomato petiole tissues, the pyrrolnitrin-resistant mutant generally failed to extend further to the stem tissues. This mutant frequently failed to reach and cross the leaf-abscission zone whereas its progression was linear in the petiole stub during the course of the experiment. This suggests that possible plant defence mechanisms in the petiole stub failed to hinder the development of either strain, but that those deployed at the level of the leaf-abscission zone were sufficient to block the slow growing mutant. One could further hypothesize that the delay in reaching the leaf-abscission zone, compared to the fast growing 


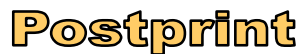

Version définitive du manuscrit publié dans / Final version of the manuscript published in : European Journal of Plant pathology, 2011, 129, 31-42, DOI: 10.1007/s10658-010-9638-5. The original publication is available at www.springerlink.com.

parental strain, may have provided enough time for the defence mechanisms to be fully activated. This hypothesis is supported by the fact that the leaf-abscission zone of BC1G20Pinoculated plants became discoloured in spite of the absence of detected mycelium, suggesting the release and accumulation of secondary plant metabolites with likely antimicrobial activity. Previous studies have reported the development of physical and chemical barriers against $B$. cinerea at the penetration site as a result of the simultaneous formation of structural barriers through the incorporation of phenolic compounds and the production of phytoalexins (Van Baarlen et al. 2004). In addition, the absence of mycelium in the stem in the case of the slow growing $\mathrm{BC} 1 \mathrm{G} 20 \mathrm{P}$ may be due to the limited induction of reactive oxygen intermediates involved in the hypersensitive reaction of the plant. Indeed, reactive oxygen intermediates were found at higher levels on bean leaves infected with aggressive isolates of $B$. cinerea when compared to less aggressive isolates (Von Tiedemann 1997). However, the role of reactive oxygen species in the ability of $B$. cinerea to invade plants remains controversial. It has been suggested that the accumulation of reactive oxygen intermediates, may be essential for successful initial infection and may facilitate B. cinerea invasion (Govrin and Levine 2000). In contrast, other studies suggested that reactive oxygen intermediates are essential for the plant to acquire resistance against this fungus. The resistance mechanism of the abscisic acid-deficient tomato mutant sitiens to $B$. cinerea is, for instance, linked to a rapid $\mathrm{H}_{2} \mathrm{O}_{2}$ accumulation (Asselbergh et al. 2007), and Unger et al. (2005) suggested that infection by this necrotrophic fungus may depend on the inhibition of the production of reactive oxygen species. Finally, to comprehend the differential behaviour in the tomato stem tissues of the two near-isogenic lines of $B$. cinerea used in this study, incorporation of phenolic compounds, production of phytoalexins and induction of reactive oxygen intermediates could be quantified in plants inoculated with either the pyrrolnitrin-resistant mutant BC1G20P or its sensitive wild-type parent isolate $\mathrm{BC} 1 \mathrm{G} 0$.

The performed in planta cytohistological investigations of infection revealed important differences between $\mathrm{BC} 1 \mathrm{G} 0$ and $\mathrm{BC} 1 \mathrm{G} 20 \mathrm{P}$ concerning the structure of mycelial compartments and the morphology of hyphal apices. While the pyrrolnitrin-sensitive wild-type parent isolate $\mathrm{BC} 1 \mathrm{G} 0$ has a pointed apex, the $\mathrm{BC} 1 \mathrm{G} 20 \mathrm{P}$ mutant has a rounded one. In addition, production of chlamydospores-like structures was observed for the pyrrolnitrin-resistant mutant BC1G20P. The chlamydospores-like structures were formed by transformation of mycelium cells and by hyphal disintegration. This phenomenon of structural change has been noticed for fungi cultured in stressful conditions. Harish et al. (1998) reported that in vitro interaction in liquid medium between Fusarium udum and the biocontrol strain AF1 of Bacillus subtilis lead to the production of chlamydospore-like structures and to an increased vacuolisation in the plant pathogen. In contrast, these authors noted that if $B$. subtilis was inoculated $24 \mathrm{~h}$ after $F$. udum (i.e. conditions less stressful for the pathogen), chlamydospore-like structures were not formed and regular conidiation was observed (Harish et al. 1998). Rijkenberg et al. (1980) showed that on tomato fruit, unsuccessful penetration of $B$. cinerea was often associated with a differentiation of germ tubes into chlamydospores at the point of attachment to epidermis. Holz et al. (2004) also reported that on fruit of nectarine, plum and pear, mycelium of $B$. cinerea formed chlamydospores when the fruits were subjected to stressful conditions, such as intermittent dry periods or long periods at low temperature (48 hours at $\left.5^{\circ} \mathrm{C}\right)$. Similarly, in our experimental conditions, the plant may exert significant stress on the slow-growing mutant BC1G20P and stimulate the production of chlamydospore-like structures. This hypothesis is reinforced by the fact that these differences in hyphal structure were not observed in in vitro culture on PDA medium (data not shown). These differences in hyphal structure may emphasize the difference in mycelial growth between $\mathrm{BC} 1 \mathrm{G} 0$ and $\mathrm{BC} 1 \mathrm{G} 20 \mathrm{P}$ in tomato tissues. 
Version définitive du manuscrit publié dans / Final version of the manuscript published in : European Journal of Plant pathology, 2011, 129, 31-42, DOI: 10.1007/s10658-010-9638-5. The original publication is available at www.springerlink.com.

In a previous study, Ajouz et al (2010) have shown that the development of resistance to pyrrolnitrin in 4 different strains of $B$. cinerea was consistently associated with a dramatic loss of aggressiveness on tomato plants and apple fruits. Together, these results suggest that the acquisition of pyrrolnitrin-resistance in $B$. cinerea is accompanied by noticeable losses of ability to develop within tomato tissues. Cytohistological examination of additional pyrrolnitrinresistant mutants in plant tissues is needed to confirm this hypothesis. In practical terms, the development of resistance to pyrrolnitrin in $B$. cinerea should not have consequences on the efficacy of pyrrolnitrin-producing biological control agents. However, the present study indicates that the mutant with resistance to pyrrolnitrin was able to develop and sporulate on the tomato petiole stub (Figure 3). During a several-month long growing season, this could enable the mutant to accomplish several cycles of infection-sporulation-dissemination on susceptible host tissues. An interesting question arising from this study would thus be whether multiplication on the plant during several generations could allow this pyrrolnitrin-resistant mutant to evolve towards greater aggressiveness.

Acknowledgements The authors gratefully acknowledge Claire Troulet and Gisèle Riqueau for excellent technical assistance in the plant tests. They also acknowledge Isabelle Bornard for the additional microscopical observations of the hyphal structure done in vitro and Veronique Decognet for critically reading the manuscript.

\section{References}

Ajouz, S., Nicot, P. C., \& Bardin, M. (2010). Adaptation to pyrrolnitrin in Botrytis cinerea and cost of resistance. Plant Pathology (in press)

Asselbergh, B., Curvers, K., França, S. C., Audenaert, K., Vuylsteke, M., Van Breusegem, F., \& Höfte, M. (2007). Resistance to Botrytis cinerea in sitiens, an abscisic acid-deficient tomato mutant, involves timely production of hydrogen peroxide and cell wall modifications in the epidermis. Plant Physiology, 144, 1863-1877

Avenot, H., Simoneau, P., Iacomi-Vasilescu, B., \& Bataille-Simoneau, N. (2005). Characterization of mutations in the two-component histidine kinase gene AbNIK1 from Alternaria brassicicola that confer high dicarboximide and phenylpyrrole resistance. Current Genetics, 47, 234-243

Blakeman, J. P. \& Fokkema, N. J. (1982). Potential for biological control of plant diseases on the phyllophane. Annual Review of Phytopathology, 20, 167-192

Büttner, P., Koch, F., Voigt, K., Quidde, T., Risch, S., Blaich, R., Brückner, B., \& Tudzynski, P. (1994). Variations in ploidy among isolates of Botrytis cinerea: implications for genetic and molecular analyses. Current Genetics, 25, 445-450

Charles, M. T., Benhamou, N., \& Arul, J. (2008). Physiological basis of UV-C induced resistance to Botrytis cinerea in tomato fruit - III. Ultrastructural modifications and their impact on fungal colonization. Postharvest Biology and Technology, 47, 27-40

Chernin, L., Brandis, A., Ismailov, Z., \& Chet, I. (1996). Pyrrolnitrin production by an Enterobacter agglomerans strain with a broad spectrum of antagonistic activity towards fungal and bacterial phytopathogens. Current Microbiology, 32, 208-212

Clark, C. A. \& Lorbeer, J. W. (1976). Comparative histopathology of Botrytis squamosa and Botrytis cinerea on onion leaves. Phytopathology, 66, 1279-1289. 


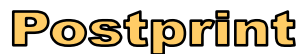

Version définitive du manuscrit publié dans / Final version of the manuscript published in : European Journal of Plant pathology, 2011, 129, 31-42, DOI: 10.1007/s10658-010-9638-5. The original publication is available at www.springerlink.com.

Decognet, V., Bardin, M., Trottin-Caudal, Y., \& Nicot, P. C. (2009). Rapid change in the genetic diversity of Botrytis cinerea populations after the introduction of strains in a tomato glasshouse. Phytopathology, 99, 185-193

Decognet, V., Ravetti, F., Martin, C., \& Nicot, P. C. (2010). Improved leaf pruning reduces development of stem cankers caused by grey mould in greenhouse tomatoes. Agronomy and Sustainable Development (in press)

Dik, A. J. \& Wubben, J. P. (2004). Epidemiology of Botrytis cinerea diseases in greenhouses. In: Y. Elad, B. Williamson, P. Tudzynski, \& N. Delen (Eds.), Botrytis: biology, pathology and control (pp. 319-333). Dordrecht, The Netherlands: Kluwer Academic Press.

El Maâtaoui, M. \& Pichot, C. (1999). Nuclear and cell fusion cause polyploidy in the megagametophyte of common cypress, Cupressus sempervirens L. Planta, 208, 345-351

Elad, Y. \& Stewart, A. (2004). Microbial control of Botrytis spp. In: Y. Elad, B. Williamson, P. Tudzynski, \& N. Delan (Eds.), Botrytis: biology, pathology and control (pp. 223-241). Dordrecht, The Netherlands: Kluwer Academic Press.

Faretra, F. \& Pollastro, S. (1993). Isolation, characterization, and genetic analysis of laboratory mutants of Botryotinia fuckeliana resistant to the phenylpyrrole fungicide CGA 173506. Mycological Research, 97, 620-624

Glidewell, S. M., Williamson, B., Goodman, B. A., Chudek, J. A., \& Hunter, G. (1997). An NMR microscopic study of grape (Vitis vinifera L.). Protoplasma, 198, 27-35

Govrin, E. M. \& Levine, A. (2000). The hypersensitive response facilitates plant infection by the necrotrophic pathogen Botrytis cinerea. Current Biology, 10, 751-757

Harish, S., Manjula, K., \& Podile, A. R. (1998). Fusarium udum is resistant to the mycolytic activity of a biocontrol strain of Bacillus subtilis AF 1. FEMS Microbiology Ecology, 25, 385-390

Holz, G., Coertze, S., \& Williamson, B. (2004). The ecology of Botrytis on plant surfaces. In: Y. Elad, B. Williamson, P. Tudzynski, \& N. Delen (Eds.), Botrytis: biology, pathology and control (pp. 9-27). Dordrecht, The Netherlands: Kluwer Academic Press.

Janisiewicz, W. J. \& Roitman, J. (1988). Biological control of blue mold and grey mold on apple and pear with Pseudomonas cepacia. Phytopathology, 78, 1697-1700

Kars, I. \& Van Kan, J. A. L. (2004). Extracellular enzymes and metabolites involved in pathogenesis of Botrytis. In: Y. Elad, B. Williamson, P. Tudzynski, \& N. Delen (Eds.), Botrytis: Biology, Pathology and Control (pp. 99-118). Dordrecht, The Netherlands: Kluwer Academic Press.

Leroux, P. (2004). Chemical control of Botrytis and its resistance to chemical fungicides. In: Y. Elad, B. Williamson, P. Tudzynski, \& N. Delen (Eds.), Botrytis: Biology, Pathology and Control (pp. 195-222). The Netherlands: Kluwer Academic Press.

Li, H. X. \& Xiao, C. L. (2008). Characterization of fludioxonil-resistant and pyrimethanilresistant phenotypes of Penicillium expansum from apple. Phytopathology, 98, 427-435

Liu, W., Leroux, P., \& Fillinger, S. (2008). The HOG1-like MAP kinase Sak1 of Botrytis cinerea is negatively regulated by the upstream histidine kinase Bos1 and is not involved in dicarboximide- and phenylpyrrole-resistance. Fungal Genetics and Biology, 45, 10621074

Nicot, P. C., Morison, N., \& Mermier, M. (2001). Optical filters against grey mould of greenhouse crops. In: C. Vincent, B. Panneton, \& F. Fleurat-Lessard (Eds.), Physical Control Methods in Plant Protection (pp. 134-145). Paris: Springer Verlag.

Prins, T. W., Tudzynski, P., Von Tiedemann, A., Tudzynski, B., Ten Have, A., Hansen, M. E., Tenberge, K., \& Van Kan, J. A. L. (2000). Infection strategies of Botrytis cinerea and related necrotrophic pathogens. In: J. W. Kronstad (Eds.), Fungal Pathology (pp. 33-64). Dordrecht, The Netherlands: Kluwer Academic Press. 
Version définitive du manuscrit publié dans / Final version of the manuscript published in : European Journal of Plant pathology, 2011, 129, 31-42, DOI: 10.1007/s10658-010-9638-5. The original publication is available at www.springerlink.com.

Rijkenberg, F. H. J., De Leeuw, G. T. N., \& Verhoeff, K. (1980). Light and electron microscopy studies on the infection of tomato fruits by Botrytis cinerea. Canadian Journal of Botany, $58,1394-1404$

Rosslenbroich, H. J. \& Stuebler, D. (2000). Botrytis cinerea - history of chemical control and novel fungicides for its management. Crop Protection, 19, 557-561

Schoustra, S. E., Debets, A. J. M., Slakhorst, M., \& Hoekstra, R. F. (2006). Reducing the cost of resistance; experimental evolution in the filamentous fungus Aspergillus nidulans. Journal of Evolutionary Biology, 19, 1115-1127

Shah, P., Gutierrez-Sanchez, G., Orlando, R., \& Bergmann, C. (2009). A proteomic study of pectin-degrading enzymes secreted by Botrytis cinerea grown in liquid culture. Proteomics, 9, 3126-3135

Staples, R. \& Mayer, A. (1995). Putative virulence factors of Botrytis cinerea acting as a wound pathogen. FEMS Microbiology Letters, 134, 1-7

Unger, C., Kleta, S., Jandl, G., \& von Tiedemann, A. (2005). Suppression of the defence-related oxidative burst in bean leaf tissue and bean suspension cells by the necrotrophic pathogen Botrytis cinerea. Journal of Phytopathology, 153, 15-26

Van Baarlen, P., Legendre, L., \& Van Kan, J. A. L. (2004). Plant defence compounds against Botrytis infection. In: Y. Elad, B. Williamson, P. Tudzynski, \& N. Delen (Eds.), Botrytis: biology, pathology and control (pp. 143-161). The Netherlands: Kluwer Academic Press.

Van Baarlen, P., Woltering, E. J., Staats, M., \& Van Kan, J. A. L. (2007). Histochemical and genetic analysis of host and non-host interactions of Arabidopsis with three Botrytis species: an important role for cell death control. Molecular Plant Pathology, 8, 41-54

Viaud, M., Fillinger, S., Liu, W., Polepalli, J. S., Le Pecheur, P., Kunduru, A. R., Leroux, P., \& Legendre, L. (2006). A class III histidine kinase acts as a novel virulence factor in Botrytis cinerea. Molecular Plant-Microbe Interactions, 19, 1042-1050

Viret, O., Keller, M., Jaudzems, V. G., \& Cole, F. M. (2004). Botrytis cinerea infection of grape flowers: light and electron microscopical studies of infection sites. Phytopathology, 94, 850-857

von Tiedemann, A. (1997). Evidence for a primary role of active oxygen species in induction of host cell death during infection of bean leaves with Botrytis cinerea. Physiological and Molecular Plant Pathology, 50, 151-166

Ziogas, B. N., Markoglou, A. N., \& Spyropoulou, V. (2005). Effect of phenylpyrrole-resistance mutations on ecological fitness of Botrytis cinerea and their genetical basis in Ustilago maydis. European Journal of Plant Pathology, 113, 83-100 


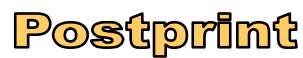

Version définitive du manuscrit publié dans / Final version of the manuscript published in : European Journal of Plant pathology, 2011, 129, 31-42, DOI: 10.1007/s10658-010-9638-5. The original publication is available at www.springerlink.com.

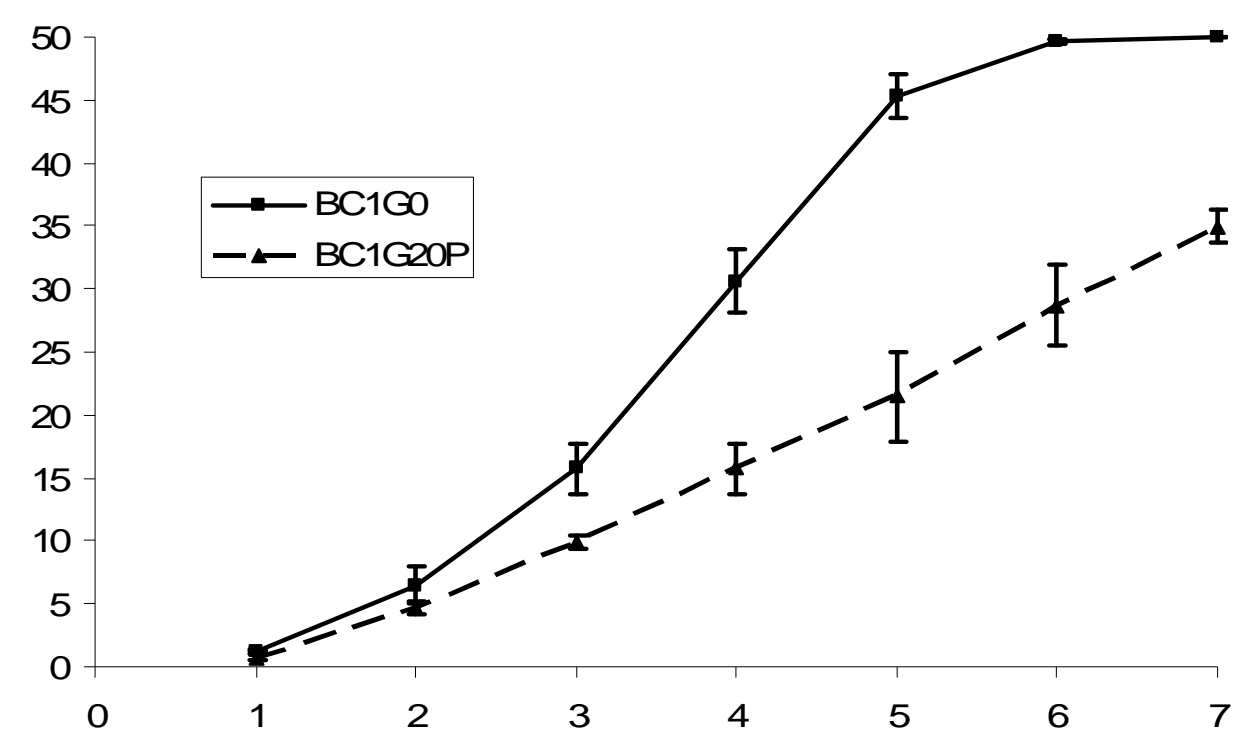

Fig. 1 Dynamics of lesion development on 50-mm long tomato petioles inoculated with either the pyrrolnitrin-sensitive wild-type parent isolate BC1G0 or the pyrrolnitrin-resistant mutant BC1G20P of Botrytis cinerea. Each point represents the mean of three repetitions. Bars indicate standard deviation of the mean of the three repetitions.

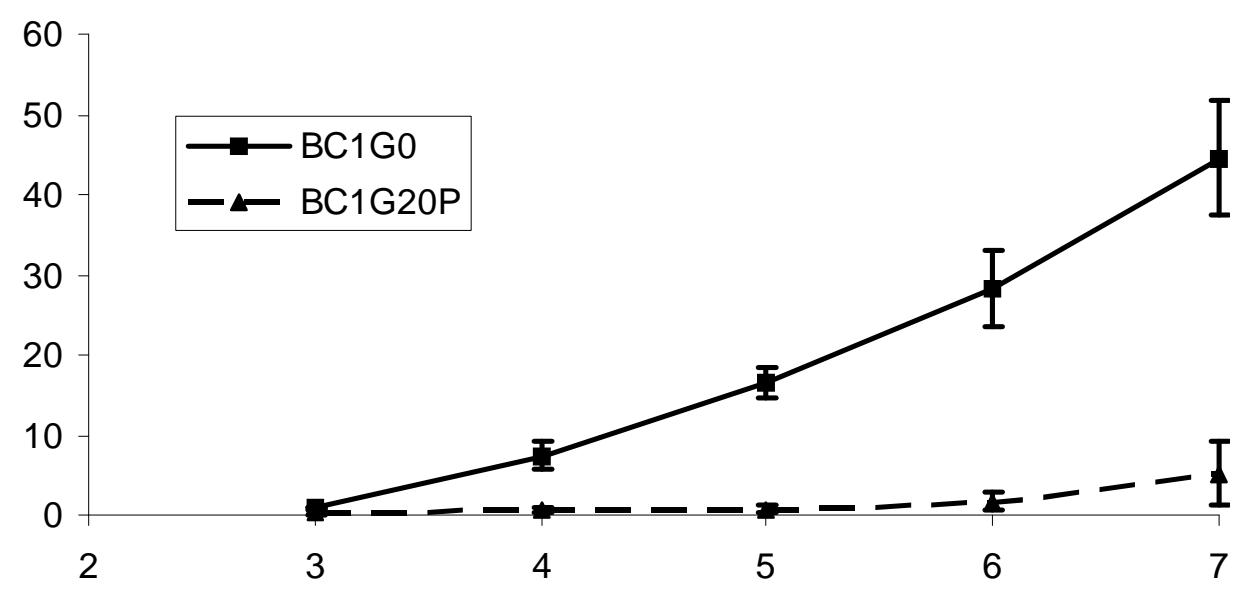

Fig. 2 Dynamics of stem lesion expansion on tomato plants inoculated with either the pyrrolnitrin-sensitive wild-type parent isolate $\mathrm{BC} 1 \mathrm{G} 0$ or the pyrrolnitrin-resistant mutant BC1G20P of Botrytis cinerea. Each point represents the mean of three repetitions. Bars indicate standard deviation of the mean of the three repetitions. 


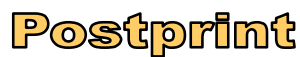

Version définitive du manuscrit publié dans / Final version of the manuscript published in : European Journal of Plant pathology, 2011, 129, 31-42, DOI: 10.1007/s10658-010-9638-5. The original publication is available at www.springerlink.com.
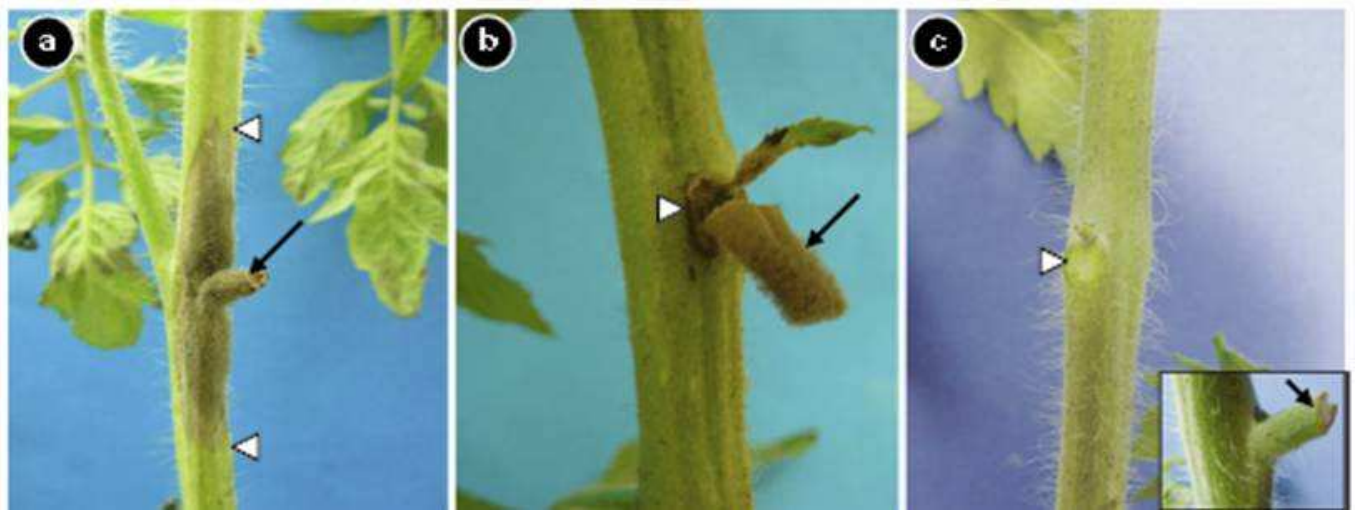

Fig. 3 Symptoms induced by the pyrrolnitrin-sensitive wild-type parent isolate BC1G0 and the pyrrolnitrin-resistant mutant BC1G20P of Botrytis cinerea on petiole stubs and stems of tomato plants after 7 days of infection. BC1G0 invades the petiole stub $(\mathrm{a}, \boldsymbol{\rightarrow})$ and extends to the stem where it generates a large lesion $(\mathrm{a}, \triangleright)$. BC1G20P initiates infection of petiole stub that detaches from the stem $(b, \rightarrow)$. Around the leaf-abscission zone, the stem exhibits browning tissues (b, $\triangleright)$. In the case of the control non-inoculated plants, the petiole does not separate from the stem $(c$, inset, $\rightarrow$ ), and when the petiole is removed, the stem is not coloured in this area $(c, D)$. 


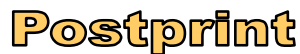

Version définitive du manuscrit publié dans / Final version of the manuscript published in : European Journal of Plant pathology, 2011, 129, 31-42, DOI: 10.1007/s10658-010-9638-5. The original publication is available at www.springerlink.com.

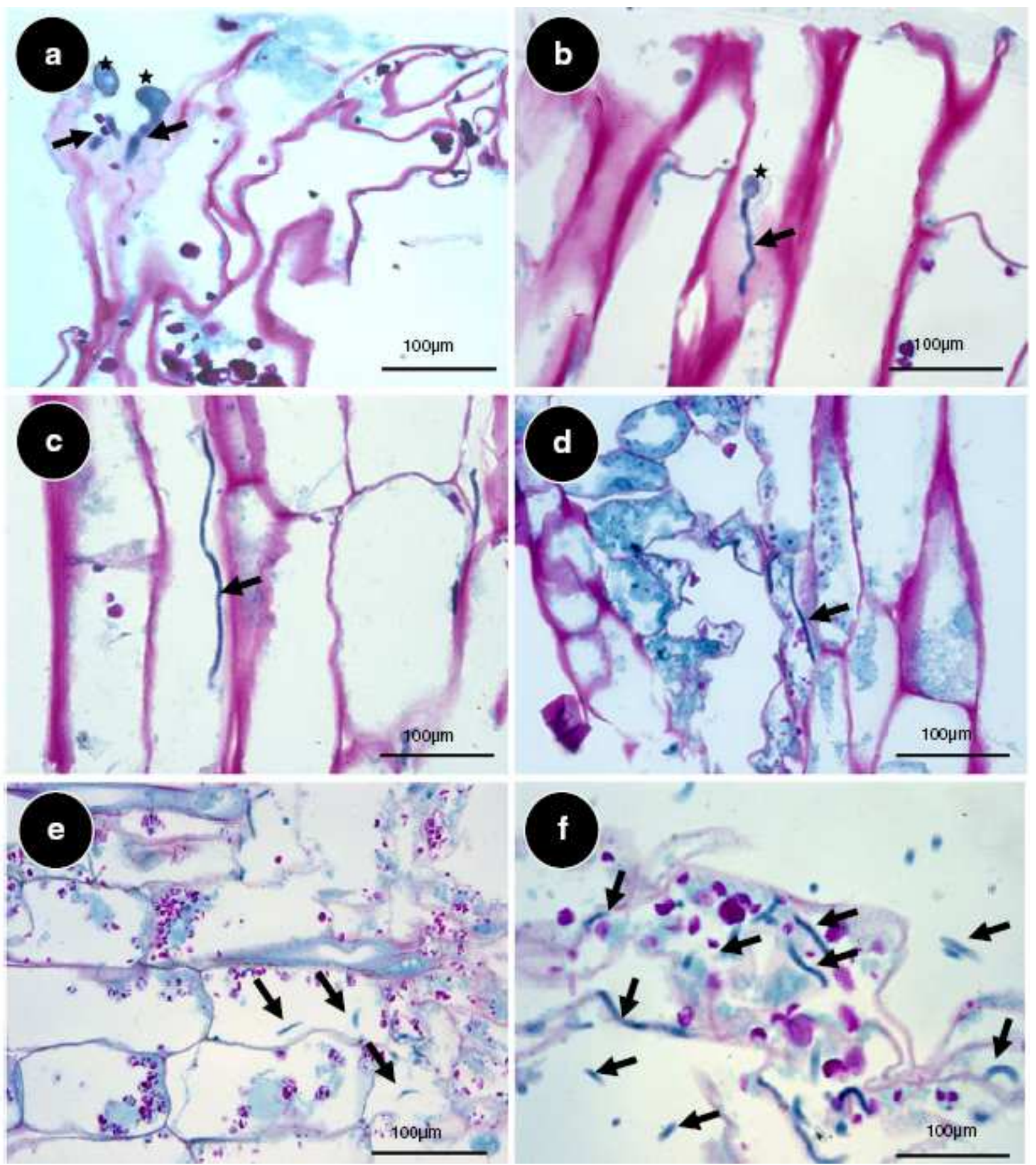

Fig. 4 Cytohistological aspects of tomato petioles infected by the pyrrolnitrin-resistant mutant BC1G20P (a, c, e) and its pyrrolnitrin-sensitive parental wild-type isolate BC1G0 (b, d, f) of Botrytis cinerea. Petiole fragments were sectioned 6 hours (a, b), 12 hours (c, d) and 24 hours (e, f) after inoculation. (a, b) Six hours after inoculation, spore germination takes place for both isolates within the injured cells $(\star)$ and forms germ-tubes that penetrate peripheral tissues $(\rightarrow)$. (c, d) After 12 hours, mycelium development gains profound petiole tissues $(\rightarrow$ ). (e, f) Plant cell alterations appear after 24 hours with BC1G0 and BC1G20P: they consist of cell wall breakdown and cell collapses due to the intensive mycelium proliferation $(\rightarrow)$. 


\section{Pంs\}}

Version définitive du manuscrit publié dans / Final version of the manuscript published in : European Journal of Plant pathology, 2011, 129, 31-42, DOI: 10.1007/s10658-010-9638-5. The original publication is available at www.springerlink.com.

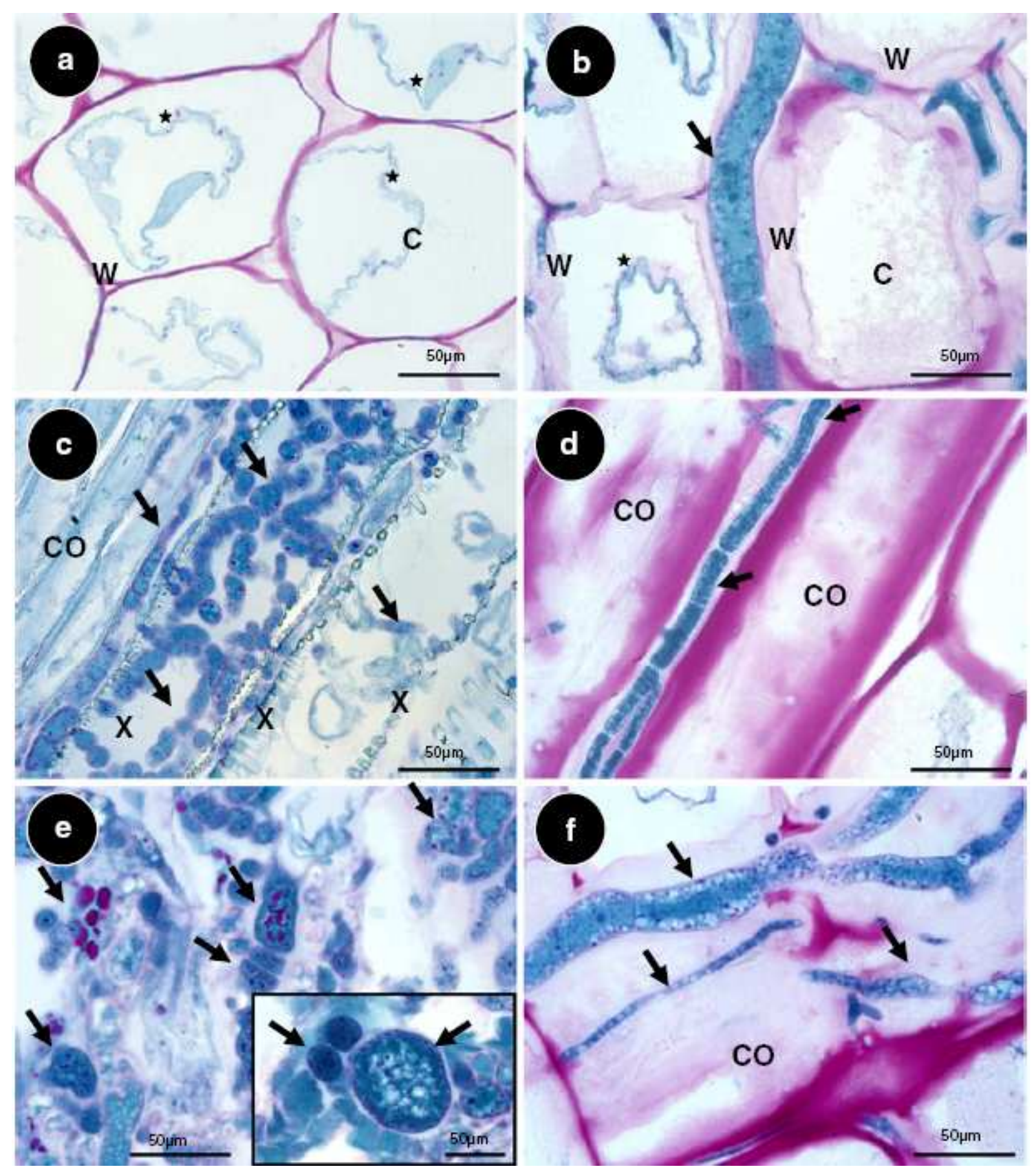

Fig. 5 Cytohistology of petiole tissues with the pyrrolnitrin-resistant mutant BC1G20P of Botrytis cinerea (a) compared to its pyrrolnitrin-sensitive parental wild-type isolate BC1G0 (b), and mycelial structures of BC1G20P (c, e) and BC1G0 (d, f). (a, b) Cell wall lyses and cell death are observed for both lines 48 hours after inoculation $(\star)$. (c, d, e, f) 72 hours after inoculation, the hyphae of BC1G20P displays short mycelial cells $(\mathrm{c}, \boldsymbol{\rightarrow})$ compared to BC1G0 hyphae $(\mathrm{d}, \rightarrow)$ and contains voluminous glycogen granules coloured in pink (e) compared to BC1G0 (f). In many places, BC1G20P mycelial compartments separate from each other yielding individual chlamydospore-like structures (e, inset). C: cytoplasm; CO: collenchyma cells; W: cell wall; X: xylem. 
Version définitive du manuscrit publié dans / Final version of the manuscript published in : European Journal of Plant pathology, 2011, 129, 31-42, DOI: 10.1007/s10658-010-9638-5. The original publication is available at www.springerlink.com.

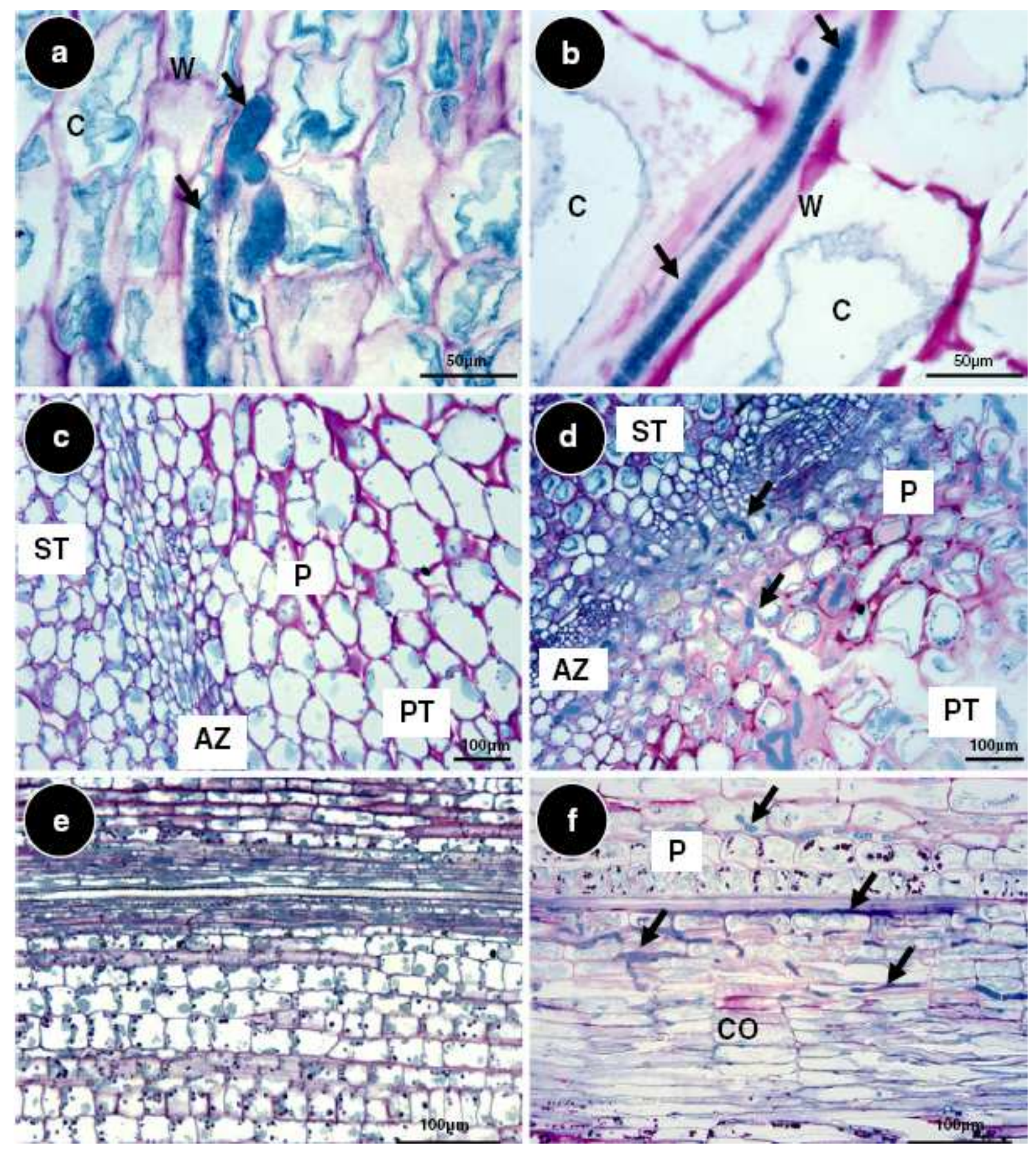

Fig. 6 Mycelium structure of the pyrrolnitrin-resistant mutant BC1G20P of Botrytis cinerea (a) and its pyrrolnitrin-sensitive parental wild-type isolate BC1G0 (b), and cytohistology of tomato stems with BC1G20P (c, e) and BC1G0 (d, f). (a, b) Micrographs showing hyphal apices in petiole parenchyma, 72 hours after inoculation. Note the destructured appearance of the mutant tips $(\mathrm{a}, \vec{\rightarrow})$ that contrasts with the healthy morphology of wild-type $(\mathrm{b}, \vec{\rightarrow})$. (c, d) Sections from the junction between petioles and stems showing the leaf-abscission zone, 72 hours after inoculation. The abscission zone of plants inoculated with the mutant is mycelium free (c) whereas wild-type mycelium induces disintegration of abscission zone cells and extends to stem tissues $(\mathrm{d}, \boldsymbol{\rightarrow})$. (e, f) Healthy and completely invaded stem tissues from tomato plants inoculated with BC1G20P and BC1G0 5 days after inoculation. AZ: leaf-abscission zone; C: cytoplasm; CO: collenchyma; P: parenchyma; PT: petiole tissues; ST: stem tissues; W: cell wall. 


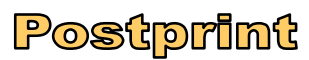

Version définitive du manuscrit publié dans / Final version of the manuscript published in : European Journal of Plant pathology, 2011, 129, 31-42, DOI: 10.1007/s10658-010-9638-5. The original publication is available at www.springerlink.com.

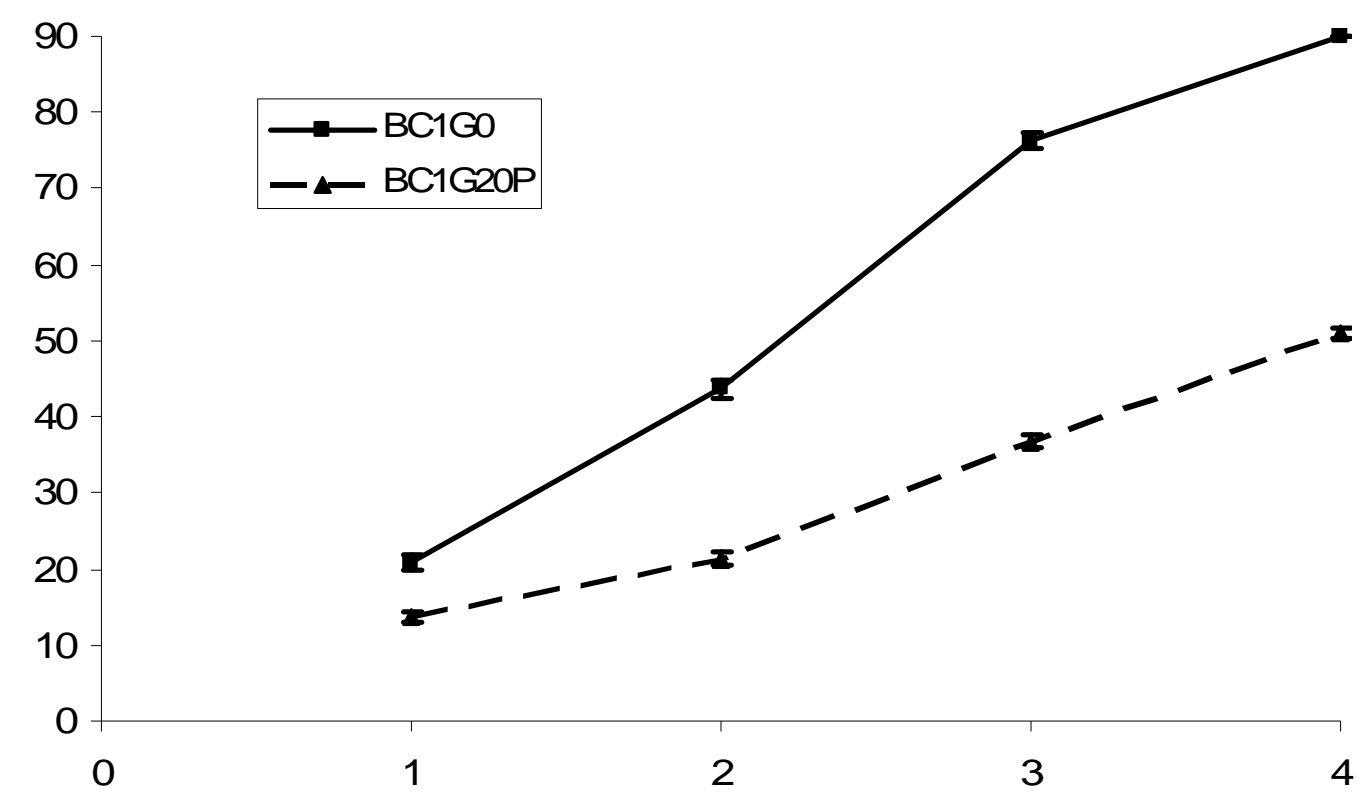

Fig. 7 Dynamics of in vitro mycelial growth of the Botrytis cinerea pyrrolnitrin-sensitive wildtype parent isolate $\mathrm{BC} 1 \mathrm{G} 0$ and the pyrrolnitrin-resistant mutant BC1G20P on PDA medium. Each point represents the mean of three repetitions. Bars indicate standard deviation of the mean of the three repetitions 